\title{
Social and Economic Conditions of Peru and Countries of the Pacific Alliance
}

\author{
Giovanni E. Reyes
}

Full, tenure professor, Universidad del Rosario,

Bogotá, Colombia

\author{
Alejandro Cheyne \\ Dean, School of Business, \\ Universidad del Rosario, \\ Bogotá, Colombia
}

\author{
Alejandro Useche \\ Tenure professor, \\ Universidad del Rosario, \\ Bogotá, Colombia
}

Doi: $10.2478 / \mathrm{mjss}-2018-0028$

\begin{abstract}
The main aim of this research is to present a study regarding the economic and social performance of Peru in recent years, compared to the countries that constitute the Pacific Alliance, namely: Chile, Colombia, Mexico and Peru. This research links Peruvian economic performance in the context of this country's political dynamics and social implications. It is important to emphasize that Peru is one of the Latin American countries less impacted by the financial crisis of 2008. One of the conclusions of the study points out that there has been a significant degree of economic growth, but the external debt levels are also rising, and this group of countries, with the exception of Mexico, to some extent, continues to be heavily dependent on exports based on raw materials, natural resources and commodities.
\end{abstract}

Keywords: Latin American economies, Peruvian economy, Pacific Alliance

\section{Introduction}

The central purpose of this paper is to establish a socio-economic characterization of Peru and the countries of the Pacific Alliance. Peru has played an exemplary role in this alliance, given that it was an initiative of President Alan Garcia Pérez, who on April 28, 2011, called a meeting with his counterparts from Chile, Colombia and Mexico. ${ }^{1}$

As a result of this meeting, the document entitled Declaration of Lima was signed. This document states that the fundamental purpose of the alliance is "to deepen the integration of these

\footnotetext{
${ }^{1}$ For more references, see the following link (in Spanish) https://alianzapacifico.net/que-es-la-alianza/\#antecedentes (last reviewed on August 26 2017). See also: PROMÉXICO (2015) Negocios Proméxico: The Pacific Alliance Issue. (Mexico, D.F.: Proméxico) specially pps, 54-60, 71-76.
} 
economies and to define actions in partnership with Chile, Colombia, Mexico and Panama in order to connect commercially with Asian countries of the Pacific Rim, while also considering the existing bilateral commercial treaties among the Acting parties".

The participating countries of the Pacific Alliance have been identified as "Latin American Cougars", in comparison to the "Asian Tigers" (South Korea, Hong Kong, Singapore, and Taiwan). Another important aspect of the Declaration of Lima establishes that the intention of the group of countries is to "encourage regional integration, as well as stronger growth, development, and competitiveness among participating countries".

The alliance tends to overlap with the current reach and state of the Andean Community (AC), a group of countries whose efforts and integration started in 1969 with the signing of the Cartagena Treaty. Initially, this treaty promoted integration as a medium for commerce development among countries, essentially making use of the re-routing of commerce, which implied the protection of local industries.

This article analyzes the main social and economic conditions of Peru in the context of the Pacific Alliance. It begins with a synthesis of the Peruvian political situation after Pedro Pablo Kuczynski's electoral triumph on June 15, 2016. The subsequent chapters focus on essential economic subject areas regarding the performance of both, individual countries and the alliance as a whole, including aspects of poverty, internal market expansion, international market conditions and commercial trade within the block.

\section{Methodology}

The formulation of this study was based on a process of reviewing documentary sources. A synthesis was made in terms of the original times of the Pacific Alliance, the principles that constitute it, and the goals that were proposed for this group of nations.

A review was made regarding the political agreements related to the implementation of economic and social mechanisms as part of the fundamental activities of the Alliance. Taken into account this frame, main features were analyzed as part of the general economic, social and political context in Latin American countries.

The following activities in this study, were devoted to characterize the Peruvian economy and society in the environment of the other countries of the Pacific Alliance, namely Chile, Colombia and Mexico. From this perspective, reference between countries that act as trade partners, allows identifying qualities of this group of nations in the economic, social and trade implications, while characterizing an important actor within them.

\section{Perú: Current Political Conditions}

Pedro Pablo Kuczynski, a center-right politician, is the current Peruvian president, who took office on July $28^{\text {th }}, 2016$. He inherits a politically divided country, considering that his triumph, in the second round of voting, came with only with 50.1 percent of the vote, against 49.9 percent for his competitor, Keiko Fujimori, from the right-wing party Fuerza Popular (FP).

One of the most important factors that gave the president-elect an advantage was the fear among voters of going back to the Alberto Fujimori era, Peru's president from 1990 to 2000. Keiko Fujimori is the daughter of the ex-president, who is currently incarcerated. However, in the legislative elections last April $10^{\text {th }}$, FP won 73 seats in the unicameral congress, out of 130 total. Congressmen are elected based on their electoral districts.

The president-elect will have to come to political agreements to ensure governability during his presidency by making pacts with other political forces in the legislative area, given that his party only won a total of 18 seats. Kenji Fujimori, Keiko's brother, has said he will run as an FP candidate in 2021 , a situation that would deepen the division among the opposition.

\section{Pacific Alliance: Main Goals}

According to updated information from official documents (see source: https://alianzapacifico.net/), 
the Pacific Alliance (PA), was created on April 28, 2011 and formally established on June 2, 2012. Based on the annual production of its four members (Chile, Colombia, Mexico, and Peru), it constitutes the eighth economy and eighth strongest exporter in the world. Its main goals, according to the Alliance Framework, are focused on:

- Complete freedom of intraregional commerce. In order to accomplish this goal, a plan was presented consisting of: (i) the immediate concession of 92 percent of customs fees; (ii) the remaining 8 percent will be distributed in periods ranging from 3 to 7 years; and additionally, (iii) a small group of products that are expected to be more strategic or sensitive will have a customs fee reduction in 10 years.

- Encouragement of integrated production. In order to promote production, employment, and internal competiveness of the block, exporting countries will consider national supplies when buying from partners; with this, the idea is to encourage intraregional commerce and further productive integration.

- Mobility of citizens. Countries have agreed on eliminating all tourist visas among members of the PA; more accurately, technical commissions are working on designing new mechanisms to ease the movement of people in the region.

- Joint promotion of commerce and investment. The institutions in charge of promoting the PA in the participating countries have agreed on several activities that will promote both commerce and investment among PA countries, contributing to the integrated constitution of a productive block.

\section{Peru and PA Countries in 2016: Economic Variables}

In a joint way, the production capability of all four countries that belong to the PA would, given its capacity for export, constitute the eighth economy and commercial block in the world. This is shown in Table 1. With this evidence, the internal market capacity in the block is notable, which could surpass 200 million people.

This is to say that, outside of the competitiveness that can be developed to inject into external markets, it also has a potential to grow economies and make them stronger based on the internal demand of countries (Govinda, 2009; Dean, 2005; Baker, 1998).

Bear in mind that within the capacity of demand, and considering spending power, Chile has the most power of acquisition despite being the least populace country. Mexico, however, which has more than double the population of other PA countries, is in second place when it comes to spending power in the internal markets.

Table 1: Pacific Alliance 2016: General GDP Characteristics, Population and GDP per Capita

\begin{tabular}{lccc}
\hline Country & $\begin{array}{c}\text { Gross Domestic Product } \\
\text { (US\$ in billions) }\end{array}$ & $\begin{array}{c}\text { Population (millions } \\
\text { of people) }\end{array}$ & $\begin{array}{c}\text { GDP per capita (Purchasing } \\
\text { Power Parity, ppp in US\$) }\end{array}$ \\
\hline Chile & 268 & 17 & 18419 \\
Colombia & 366 & 47 & 10792 \\
Mexico & 1177 & 115 & 15312 \\
Peru & 199 & 30 & 10719 \\
\hline
\end{tabular}

Source: The Economic Commission for Latin America and the Caribbean (ECLAC) (2017) Preliminary Overview for the Economies of Latin America and the Caribbean 2016. (Santiago de Chile, Chile: ECLAC); and data from the International Monetary Fund. (See: http://www.imf.org/external/index.htm).

On the same subject, Colombia's buying power is very similar to Peru's, according to the GDP per 
capita. In fact, one of the biggest criticisms of the economic model in these countries is that they have not been able to achieve desirable and positive results regarding the internal levels of inequality. This situation also applies in Chile and Mexico.

Mexico and Brazil constitute the two biggest economies in Latin America, and together they represent almost 70 percent of the regional GDP. Chile, Colombia and Peru belong to the group of medium-sized economies. This group also includes Venezuela and, most significantly, Argentina.

\section{Peru and Pacific Alliance Countries 2015 and 2016: Economic Behavior}

In accordance with official figures provided by the Economic Commission for Latin America and the Caribbean (ECLAC), the economic growth perspectives by the end of this year confirm, in general, the impact that the end of the era of high price raw materials and regional exports have had (those high prices operating from 2003 to 2014).

Nonetheless, as is shown in Table 2, Peru maintains remarkable performance, the best in the group. This confirms that Costa Rica, Panama, Peru, and Uruguay are the countries that have maintained strong performance, in social and economic terms, according to the statistics in Latin America, see Economic Commission for Latin America and the Caribbean (ECLAC).

Table 2: Peru and the Pacific Alliance 2016: Macroeconomic Performance Perspective

\begin{tabular}{lccc}
\hline Country & $\begin{array}{c}\text { Economic Growth } \\
\text { (\% of GDP variation) }\end{array}$ & $\begin{array}{c}\text { Inflation } \\
(\%)\end{array}$ & $\begin{array}{c}\text { Open Unemployment } \\
(\%)\end{array}$ \\
\hline Chile & 1.5 & 4.1 & 6.8 \\
Colombia & 2.5 & 7.3 & 9.8 \\
Mexico & 2.4 & 2.9 & 4.1 \\
Peru & 3.7 & 3.1 & 6.0 \\
\hline
\end{tabular}

Source: The Economic Commission for Latin America and the Caribbean (ECLAC) (2017) Preliminary Overview for the Economies of Latin America and the Caribbean 2016. (Santiago de Chile, Chile: ECLAC); and data from the International Monetary Fund. (See: http://www.imf.org/external/index.htm).

Rates of inflation and unemployment are more concerning in Colombia's case. Keep in mind that this is the country within the group with the highest rates in both of these categories.

In the case of Peru, similar to the drop in the economic growth of PA countries is an association to international export prices. During the period from 2003-2014, the income growth due to export in Latin American countries was mainly a result of the price of products in foreign markets, more than the amount of exports. Table 3 details the economic growth in the PA countries in terms of the productive sector. For Chile and Colombia, the agricultural sector tends to shrink. In Colombia's case, the situation becomes worse when considering that industry is showing negative growth.

\section{Peru and Alliance Countries: Inflation and Employment Variables}

Table 4 shows inflation figures, and in accordance with them, increased levels of consumer prices are evidently controlled in Mexico and Peru. When considering Colombia in terms of these values, the figures are concerning. In this case, it is also clear that in 2014 the Colombian market was benefiting from the monetary appreciation of its currency.

As is normal with the economic structure in Latin America, a high value of local currencies tends to more intensely promote the import sector, because it lowers the value of the reference currency, in this case the U.S. dollar. In a parallel way, it is expected that when the value of 
currency appreciates, the export sector weakens. These two factors are redundant in that they plunge the commercial balance with levels of deficit (Gilpin, 2001; Barrow, 2006).

Table 3: Pacific Alliance Countries 2016: Economic Growth by Sector (\% annual variation)

\begin{tabular}{lcccc}
\hline Economic Sector & Chile & Colombia & Mexico & Peru \\
\hline Agriculture & -0.6 & -2.6 & 4.3 & 3.8 \\
Industrial & 2.6 & -0.7 & 13.6 & 5.6 \\
Transportation & 4.2 & 4.1 & Not available & Not available \\
Construction & 8.4 & 3.6 & 17.4 & 3.4 \\
Commerce & 8.1 & 4.1 & 9.7 & 8.8 \\
Mining and Energy & 4.3 & 5.9 & -0.1 & -0.2 \\
\hline
\end{tabular}

Source: The Economic Commission for Latin America and the Caribbean (ECLAC) (2017) Preliminary Overview for the Economies of Latin America and the Caribbean 2016. (Santiago de Chile, Chile: ECLAC); and data from the International Monetary Fund. (See: http://www.imf.org/external/index.htm).

However, the strength of currency also contributes to lower levels of job creation. No jobs are created because we are not exporting nor creating productive jobs in tradable goods, because it is cheaper to import than to produce for the internal market. This frames some of the explanations of the declines in the productive sector, one which generates high levels of employment, as in the case of agriculture and industry.

Table 4: Peru and the Pacific Alliance 2013-2016: Inflation (Annual variation rate $\%$ at the end of each period)

\begin{tabular}{lccc}
\hline Country & $\mathbf{2 0 1 4}$ & $\mathbf{2 0 1 5}$ & $\mathbf{2 0 1 6}$ \\
\hline Chile & 3.1 & 4.6 & 4.0 \\
Colombia & 1.9 & 3.7 & 5.9 \\
Mexico & 4.0 & 4.1 & 2.5 \\
Peru & 2.9 & 3.2 & 3.7 \\
\hline
\end{tabular}

Source: The Economic Commission for Latin America and the Caribbean (ECLAC) (2017) Preliminary Overview for the Economies of Latin America and the Caribbean 2016. (Santiago de Chile, Chile: ECLAC).

On the contrary, when currency moves toward devaluation or depreciation, this trend would focus on promoting more exports and provoking a decline in imports. This is especially true for the latter, given that the hard currency or reference currency becomes more expensive. In terms of unemployment, as previously mentioned, Colombia is the most concerning case. With relatively high unemployment and inflation rates, the country is at risk of experiencing the phenomenon of stagflation (Rahim, 2010; Piketty, 2013).

Either way, the results of open unemployment are influenced by or related to the levels of the underground economy or informal sector. This is influenced by underemployment, which tends to increase in Chile and Peru, although with levels that seem to be controlled or stabilized. There is truth in the trend that the higher the growth, the greater the chances at increasing inflation, but without any growth, even with stability, job creation will not be active enough and internal markets will not expand.

The conditions in Peru are such that salaries have greater increase in buying ability. This tends to establish a higher aggregated demand in the domestic market, and with that, a factor that promotes business competitiveness, which is supplemental to the intersection of businesses in the international market. 
Table 5: Peru and the Pacific Alliance 2014-2016: Open Unemployment (annual rates)

\begin{tabular}{lccc}
\hline País & $\mathbf{2 0 1 4}$ & $\mathbf{2 0 1 5}$ & $\mathbf{2 0 1 6}$ \\
\hline Chile $^{1}$ & 5.9 & 6.4 & 6.3 \\
Colombia $^{2}$ & 10.6 & 9.9 & 9.6 \\
Mexico $^{3}$ & 5.7 & 5.8 & 5.1 \\
Peru $^{4}$ & 5.9 & 6.0 & 6.5 \\
\hline
\end{tabular}

Notes: $1 /$ Chile, national total;

2/ Colombia, 13 main cities;

3/ Mexico, urban areas;

4/ Peru, Lima metropolitan area.

Source: The Economic Commission for Latin America and the Caribbean (ECLAC) (2017) Preliminary Overview for the Economies of Latin America and the Caribbean 2016. (Santiago de Chile, Chile: ECLAC).

\section{Peru and Pacific Alliance Countries 2005-2013: Human Poverty Index}

The stability of prices, job creation and economic growth tend to generate higher levels of wellbeing in the population. Inasmuch as these three variables - key indicators of a nation's economic performance- remain sustainable, poverty levels tend to drop. The variables of this behavior are shown in Table 6.

Comparatively, poverty statistics show Chile exhibits that indicator in a similar way to developed countries. Keep in mind that in the United States, the poverty rate is at 14 percent. In terms of poverty, -which is directly related to street violence- countries with lower rates are Uruguay, Chile, Costa Rica and, to some extent, Trinidad and Tobago.

In comparing the group of countries that belong to the PA, Peru shows that it has the highest drop in poverty rate since 2005. This owes fundamentally to job creation, each time that institutions -a situation that is similar for Latin American countries- show a lot of weaknesses in terms of national coverage and delivering public services and quality goods. This is worsening, particularly in the areas of education, health and housing (Govinda, 2009).

Table 6: Pacific Alliance 2005, 2010, 2016: Population Living under the Poverty Line (\% of total population)

\begin{tabular}{lccc}
\hline País & $\mathbf{2 0 0 5}$ & $\mathbf{2 0 1 0}$ & $\mathbf{2 0 1 6}$ \\
\hline Chile & 14 & 11 & 8 \\
Colombia & 45 & 32 & 28 \\
Mexico & 32 & 37 & 32 \\
Peru & 52 & 26 & 24 \\
\hline
\end{tabular}

Source: The Economic Commission for Latin America and the Caribbean (ECLAC) (2017) Social Panorama of Latin America and the Caribbean 2016. (Santiago de Chile, Chile: CEPAL).

It is clear that the poverty rate in Chile tends to lower with less intensity, but it is important to remember that the original rates, in 2005 , of poverty in the country make a drop very difficult. A contrary situation occurs when poverty and/or unemployment rates are high. In this last situation, it can be relatively easy to reduce these standards.

\section{Peru and Pacific Alliance Countries: Investment in Real Economy}

It is known that there are two big economic sectors that act jointly, but are excluded when it comes to obtaining capital. On one hand there is the real sector. It is the most important sector for promotion and consolidation of development, given that is directly related to creating jobs and generating quality goods and services. 
On the other hand, there is the finance sector of economy. It is the sector in which profits are obtained through trading transactions, buying and selling stocks, bonds, and in general financial derivatives. This sector does not generate, in a strict way, a production of quality goods and services, but instead the transaction is produced through papers and titles.

In Table 7, information about gross fixed capital formation in the Pacific Alliance countries shows a relatively stable situation in these nations, with investment ranges, based on gross domestic product (GDP), going from 21 to 26 percent. Peru is the country that maintains, on average, higher rates, with mathematical but not substantial differences against the figures of other nations.

Table 7: Peru and the Pacific Alliance 2011-2016: Gross Fixed Capital Formation (As a \% of GDP)

\begin{tabular}{lcccccc}
\hline Country & $\mathbf{2 0 1 1}$ & $\mathbf{2 0 1 2}$ & $\mathbf{2 0 1 3}$ & $\mathbf{2 0 1 4}$ & $\mathbf{2 0 1 5}$ & $\mathbf{2 0 1 6}$ \\
\hline Chile & 21 & 23 & 24 & 24 & 22 & 22 \\
Colombia & 21 & 22 & 25 & 24 & 26 & 26 \\
Mexico & 21 & 22 & 22 & 22 & 22 & 21 \\
Peru & 24 & 25 & 26 & 26 & 25 & 25 \\
\hline
\end{tabular}

Source: The Economic Commission for Latin America and the Caribbean (ECLAC) (2017) Preliminary Overview for the Economies of Latin America and the Caribbean 2016. (Santiago de Chile, Chile: ECLAC).

The foreign direct investment rate is associated with credibility of institutions and the economic and socio-political conditions of a country. The required trust to attract productive investment, especially in the real economy, is connected to six essential factors: (i) political stability; (ii) macroeconomic stability-including the exchange type; (iii) physical infrastructure; (iv) education and in general human capital training; (v) institutions and constitutional state; and (vi) cultural factors (Lizzeri, 2004; Reyes, 2001; Stiglitz, 2013).

Table 8: Peru and the Pacific Alliance 2011-2016: Foreign Direct Investment (US\$ in millions)

\begin{tabular}{lccc}
\hline Country & $\mathbf{2 0 1 1}$ & $\mathbf{2 0 1 3}$ & $\mathbf{2 0 1 6}$ \\
\hline Chile & 7902 & 8956 & 9950 \\
Colombia & 15646 & 8557 & 12252 \\
Mexico & -2739 & 32032 & 16837 \\
Peru & 11840 & 9161 & 7789 \\
\hline
\end{tabular}

Source: The Economic Commission for Latin America and the Caribbean (ECLAC) (2017) Preliminary Overview for the Economies of Latin America and the Caribbean 2016. (Santiago de Chile, Chile: ECLAC).

Table 9: Peru and the Pacific Alliance Gross External Debt (US\$ in millions at the end of each period)

\begin{tabular}{lccc}
\hline Country & $\mathbf{2 0 1 3}$ & $\mathbf{2 0 1 4}$ & $\mathbf{2 0 1 5}$ \\
\hline Chile & 132632 & 145666 & 148716 \\
Colombia & 91923 & 101212 & 108199 \\
Mexico & 254793 & 282479 & 291029 \\
Peru & 60823 & 64512 & 63789 \\
\hline
\end{tabular}

Source: The Economic Commission for Latin America and the Caribbean (ECLAC) (2017) Preliminary Overview for the Economies of Latin America and the Caribbean 2016. (Santiago de Chile, Chile: ECLAC). 
The Pacific Alliance countries demonstrate consistency in attracting foreign direct investment. The only negative figure belongs to Mexico in 2011. One of the factors that can explain this situation is the impact of the financial crisis that had an inflexion point in September of 2008 with the bankruptcy of the Lehman Brothers bank.

As is known, the Mexican economy is intimately related to the American economy, which is constituted in the natural market of the Latin American state and in the sub-region of Central America and the Caribbean; close to 87 percent of Mexican exports have the American market as their destination.

\section{Peru and Pacific Alliance Countries: Foreign Trade}

As is shown in Table 10, the balance between quality goods and services in the Pacific Alliance countries has been in deficit for years. This is happening because exports have been losing their billing value externally and therefore, relative levels of monetary depreciation have presented themselves. Even though Mexico, along with Brazil and Costa Rica, are the countries that have diversified their exports the most, Peru, Chile, and Colombia are highly dependent on raw material for products that are sold internationally. In general, one of the main problems of competitiveness in Latin America lies in the need to strengthen the levels of added-value of exports.

Table 10: Peru and the Pacific Alliance 2015-2016: Balance Of Goods And Services (US\$ in millions)

\begin{tabular}{lcc}
\hline Country & $\mathbf{2 0 1 5}$ & $\mathbf{2 0 1 6}$ \\
\hline Chile & -1582 & -4010 \\
Colombia & -2745 & -11268 \\
Mexico & -11893 & -15024 \\
Peru & -3077 & -5361 \\
\hline
\end{tabular}

Source: The Economic Commission for Latin America and the Caribbean (ECLAC) (2017) Preliminary Overview for the Economies of Latin America and the Caribbean 2016. (Santiago de Chile, Chile: ECLAC).

Not meeting this goal means maintaining the current productive environment which is very vulnerable to the impact of the international economy. Meanwhile, the local market cannot generate enough jobs with good remuneration. In fact, based on the advance of technology, this scenario constitutes and consolidates sectors of cutting-edge technology-informatics, cybernetics, biotechnology, satellite and complex systems of computation and nanotechnology- every time there are more required levels of investment in order to create high compensation jobs (Scott, 2001; Ruger, 2010; Zimmermann, 2006).

Table 11: Peru and the Pacific Alliance 2015-2016: Export Rates $(2010=100)$

\begin{tabular}{lcccc}
\hline Country & \multicolumn{2}{c}{ Value } & \multicolumn{2}{c}{ Volume } \\
& $\mathbf{2 0 1 5}$ & $\mathbf{2 0 1 6}$ & $\mathbf{2 0 1 5}$ & $\mathbf{2 0 1 6}$ \\
\hline Chile & 107 & 106 & 110 & 109 \\
Colombia & 139 & 92 & 139 & 128 \\
Mexico & 133 & 128 & 124 & 130 \\
Peru & 110 & 93 & 105 & 103 \\
\hline
\end{tabular}

Source: The Economic Commission for Latin America and the Caribbean (ECLAC) (2017) Preliminary Overview for the Economies of Latin America and the Caribbean 2016. (Santiago de Chile, Chile: ECLAC).

When, on the other hand, export rates are compared, both in terms of value and quantity or volume, it is clear that Colombia and Peru have seen decreases in the value of their products internationally. 
This situation fundamentally contrasts with Mexico's experience, which has seen a rise in the value of its products by 28 percent.

Table 12: Peru and the Pacific Alliance 2015-2016: Import Rates $(2010=100)$

\begin{tabular}{lcccc}
\hline Country & \multicolumn{2}{c}{ Value } & \multicolumn{2}{c}{ Volume } \\
& $\mathbf{2 0 1 5}$ & $\mathbf{2 0 1 6}$ & $\mathbf{2 0 1 5}$ & $\mathbf{2 0 1 6}$ \\
\hline Chile & 123 & 106 & 116 & 112 \\
Colombia & 160 & 139 & 147 & 140 \\
Mexico & 133 & 133 & 123 & 128 \\
Peru & 141 & 128 & 127 & 128 \\
\hline
\end{tabular}

Source: The Economic Commission for Latin America and the Caribbean (ECLAC) (2017) Preliminary Overview for the Economies of Latin America and the Caribbean 2016. (Santiago de Chile, Chile: ECLAC).

Again, the diversified exportable supply of Mexico presents itself. This diversification and having products with a higher added-value protects a country's economy from adverse impacts that can occur in international markets. Additionally, Mexico represents almost 47 percent of what is exported in Latin America, which is to say, half of the international-regional insertion via exports.

When it comes to export volume, all four countries demonstrate successful efforts. Again, the difficulty comes in that products have low added-value and, therefore, lowers competitiveness that can be developed in the international market.

Aside from these conditions, import value rates spike, bearing in mind what happened in Colombia, the country with higher activity in terms of import volume. This rate increased 40 percent from 2010-2015. The drop in export rates in terms of the value of exports contrasts with the rate of increase of export value. In effect, these product values, when compared to the exterior, tend to increase. Note the 60 percent increase that Colombian imports had in 2014, compared to the levels in 2010.

Table 13: Peru and the Pacific Alliance 2011-2016: Trade Terms $(2010=100)$

\begin{tabular}{lcccc}
\hline Country & $\mathbf{2 0 1 1}$ & $\mathbf{2 0 1 2}$ & $\mathbf{2 0 1 4}$ & $\mathbf{2 0 1 6}$ \\
\hline Chile & 95 & 91 & 93 & 88 \\
Colombia & 108 & 92 & 100 & 72 \\
Mexico & 105 & 99 & 104 & 95 \\
Peru & 105 & 94 & 99 & 89 \\
\hline
\end{tabular}

Source: The Economic Commission for Latin America and the Caribbean (ECLAC) (2017) Preliminary Overview for the Economies of Latin America and the Caribbean 2016. (Santiago de Chile, Chile: ECLAC).

When considering how the values of exports drop and the prices of imports increase, it is not strange to see the terms of trade weaken. This is shown in Table 13. This is to say, developing countries in Latin America generally buy with spiking trends in prices, while their products are propped-up or lose value.

This is all a long-term trend, given that there are circumstantial situations that cause the prices in Latin American exports to experience spikes, as it occurred between 2003 and 2014. Regarding the trade of goods among Pacific Alliance countries, low levels are shown. Tables 14 and 15 disclose those amounts of trade. In no case do they surpass five percent of the total. Although a relatively high level, for the standards of the group the import situation in Colombia and Mexico reaches 9 percent value.

This trade weakness is found in the insignificance of other elements of integration. A recent one, since mid 2015, has been the connection to trade investors. To this effect, a process has begun to homologate procedures and create mechanisms involving stock market processes for 
participating countries. Recently, Argentina, with the government of Mauricio Macri, has shown interest in joining the Pacific Alliance. Currently, it has been accepted as an observing member. The propensity would be to solidify the block with other new members, such as interested countries like Argentina, Costa Rica and Panama.

Beginning on May 1, 2016, the document Additional Protocol to the Framework of the Pacific Alliance was signed and came into effect. Among the benefits that are afforded by this document are the liberation of fees for 92 percent of products and export mechanisms to third countries. Some of these most recent cases include China, Japan, Singapore, Malaysia, and Australia.

Table 14: Pacific Alliance 2016: Exports of Member Countries (as a \% of total)

\begin{tabular}{lcccc}
\hline Origin & \multicolumn{4}{c}{ Destination } \\
\hline Chile & ---- & Colombia & Mexico & Peru \\
Colombia & 2.7 & 1.1 & 1.7 & 2.5 \\
Mexico & 0.5 & 1.2 & 1.5 & 2.1 \\
Peru & 4.1 & 2.1 & --- & 0.5 \\
\hline
\end{tabular}

Source: The Economic Commission for Latin America and the Caribbean (ECLAC) (2017) Preliminary Overview for the Economies of Latin America and the Caribbean 2016. (Santiago de Chile, Chile: ECLAC).

One of the goals of the coordination of tourism among the agencies of the participating countries has been to increase this category by 11 percent among members, plus 15 percent with visitors from China. The promoting agencies of commerce are working on establishing productive supply chains. These last ones would include components of ready-to-assemble furniture. Other supply chain categories refer to Colombian pineapple, chrysanthemum, auto parts, processed fruit, packaging, along with food goods. The textile industry is also showing interest in taking advantage of the complementarity in the design process, elaboration, and garment distribution.

Table 15: Pacific Alliance 2016: Imports of Member Countries (as a \% of total)

Origin

\section{Destination}

\begin{tabular}{lllll} 
& Chile & Colombia & Mexico & Peru \\
\hline Chile & ---- & 1.5 & 0.4 & 3.1 \\
Colombia & 2.2 & ---- & 0.2 & 3.4 \\
Mexico & 3.2 & 9.2 & ---- & 4.2 \\
Peru & 2.2 & 1.5 & 0.2 & - --- \\
\hline
\end{tabular}

Source: The Economic Commission for Latin America and the Caribbean (ECLAC) (2017) Preliminary Overview for the Economies of Latin America and the Caribbean 2016. (Santiago de Chile, Chile: ECLAC).

\section{Final Considerations and Conclusions}

Peru's economy plays an important role in the Pacific alliance not only because of its relatively large market size, also because of the dynamism of its economy, which includes employment generation, inflation control and promotion of investments in the real economy sector. The Peruvian 
economy together with the Colombian economy have been quite stable in their economic growth.

The economy of Chile, in the context of the Pacific Alliance, is stable and has also made it possible to expand employment and entrepreneurship opportunities within the country. Hence, Chile presents significant improvements in both, extreme and non-extreme poverty rates. The Mexican economy shows, as expected, its greatest link with the American market and society. The latter is its natural market; approximately 87 percent of Mexican exports are sent for the United States market.

Peru's social conditions are characterized by a highly significant improvement, particularly in the last decade. This feature is encouraging given that Peru's social conditions are experiencing pro-poor economic growth, opening up opportunities for people through employment and business creation, which would tend to consolidate inclusive markets.

\section{References}

Acemoglu, D. \& Robinson, J. (2000). Why did the West extend the franchise? Democracy,inequality, and growth in a historical perspective. Quaterly Journal of Economics 115 (4),1167- 1200.

Baas, S. (2002) Sustainable Development Strategies. London, OECD.

Bailey, K. (2008) Methods of social research.New York: The Free Press.

Baker, D. et. al. (1998) Globalization and progressive economic policy. Cambridge, U.K.: Cambridge University Press.

Barrow, C. (2006) Environmental Management for Sustainable Development. London, Routledge.

Dean, H., Bonvin, J. (2005). 'Developing capabilities and rights in welfare-to-work policies.' European Societies 7(1), 3-26.

Duménil G. \& Lévy D. (2004) Capital Resurgent: Roots of the Neoliberal Revolution.Boston: Harvard University Press.

Duménil G. \& Lévy, D. (2001). "Costs and Benefits of Neoliberalism. A class analysis", Review of International Political Economy, Vol. 8, num. 4, pp. 578-607.

Economic Commission for Latin America and the Caribbean (ECLAC) (2017) Preliminary Overview for the Economies of Latin America and the Caribbean 2016. (Santiago de Chile, Chile: ECLAC).

Gilpin, R. (2001) Global Political Economy: Understanding the International Economic Order.Princeton: Princeton University Press.

Global Connectivity Organization (2009) The Sustainable Development Timetable. New York: International Institute for Sustainable Development, IISD.

Govinda, P. (2009) 'In the name of "poor and marginalized": Politics of NGO Activism with Dalit Women in Rural North India', Journal of South Asian Development 4(1): 45-64.

Lizzeri, A. \& Persico, N. (2004). Why did the elites extend the franchise? Democracy and the scope of government with an application to Britain's "Age of Reform". Quarterly Journal of Economics 119 (4), 707765.

Meyer, J. et.al. (1977). Institutionalized organizations: Formal structure as myth and ceremony. American Journal of Sociology, 83, 340-363.

Nussbaum, M. (2004). 'Beyond the Social Contract: Capabilities and Global Justice. An Olaf Palme Lecture, Oxford, 19 June 2003.' Oxford Development Studies, 32(1).

Piketty, T. (2013) "Capitalism in the XXI Century"New York: Belknap Press.

Powell, W. \& DiMaggio, P. (1991).The new institutionalism in organizational analysis. Chicago: University of Chicago Press.

Reyes, G. (2001). Globalization and Latin American Economies 1960-1995: A Network Analysis Model and Implications for Economic Growth. (Doctoral Dissertation, University of Pittsburgh, Hathi Trust Digital Library; see from catalog: http://catalog.hathitrust.org/Record/007250231)..

Reyes, G. \& Briceño, A. (2010). Propuesta de modelo financiero para crecimiento corporativo sostenible. Finanzas y Política Económica, 2(2), 57-64.

Ruger, Jennifer (2004). 'Ethics of the social determinants of health.' Lancet 364, 1092-97.

Ruger, J. (2010). "Health capability: conceptualization and operationalization". American Journal of Public Health. 100, 41-49.

Scott, W. R. (2001). Institutions and organizations, 2nd edn. Thousand Oaks, CA: Sage.

Sen A. (2011) Development as Freedom. New York: Random.

Stiglitz, J. (2003) The Happy Nineties and the Seed of Destruction. New York: Random.

Stiglitz, J. (2013) Price of Inequality: How Today's Divided Society Endangers Our Future. New York: Norton \& Company.

Todaro, M. (2011) Economic Development. New York: Prentice-Hall, 11nd. Edition. 
Whiteside, N. (2011). Creating collective capability: historical perspectives on co-ordinated public action?, in Rogowski, Ralf, Salais, Robert and Whiteside, Noel. Eds. Transforming European Employment Policy: labour market transitions and the promotion of capability. London: Edward Elgar P.

Zimmermann, B. (2006). 'Pragmatism and the Capability Approach: Challenges in Social Theory and Empirical Research.' European Journal of Social Theory 9(4), 467-484. 